\title{
The Historical Evolution, Main Experience and Enlightenments of the Relationship between Government and Social Organizations since the Foundation of China
}

\author{
Li-Yuan CAO ${ }^{1, a,{ }^{*},(1)}$, Qing $\mathrm{LI}^{2, b}$ \\ ${ }^{12}$ School of Humanities and Social Sciences, North China Electric Power University, Baoding, P.R. \\ China, 071003 \\ acaoliyuan1983@163.com, b1224974273@qq.com
}

Keywords: Government, Social organizations, Relationship, Historical evolution, Cooperative partnership.

\begin{abstract}
In China, the relationship between government and social organizations has been promoting the emergence and development of social organizations directly, and studying the historical evolution of the relationship between them has much significance for the future development of social organizations. Since the foundation of China, the relationship between government and social organizations has experienced roughly 4 stages, including the period of control and management, the period of attachment and dependence, the period of half-attachment and half-independence, and the period of preliminary exploration of cooperative partnership. Through clearing up the development process, it's not hard to find that with the improvement of market economy and maturity of civil society, the two-way interaction between government and social organizations will increase gradually, and forming partnership in provision of public service is an inevitable trend.
\end{abstract}

\section{Introduction}

With further development of market economy and social transformation, the extent of social fragmentation is deepening, and the difficulty of social governance is increasing continuously. As a communication bridge between the state and society, social organizations are important forces to rely on to rebuild the social system and achieve good social governance. In 2013, the Third Plenary Session of the 18th CPC Central Committee regarded social organizations as an important part of deepening social system reform and innovating social governance system. In this context, it can help us understand history, analyze the present situation, and grasp the trend comprehensive and accurately to figure out the development process of relationship between government and social organizations since the foundation of China, in order to promote social organizations toward more healthy direction.

\section{The Development Process of Relationship between Government and Social Organizations since the Foundation of China}

The concept of social organizations was put forward in the Sixth Plenary Session of the Sixteenth CPC Central Committee at first, and it is a reformation of non-government organizations, non-profit organizations, civil groups, social groups and so on, which has been widely used in recent years. It refers to all kinds of organizations that are committed to social governance and services, which are different from governments in national system and enterprises in market system, so they belong to organizations of "social system". ${ }^{[1]}$ According to this argument, social organizations should include social groups, foundations, private non-enterprise units and grassroots organizations which are not recorded officially.

The social organizations of Western capitalist countries were generated from government failure and market failure, while Chinese social organizations developed under the support of government. To some extent, in China, the change of relationship between government and social organizations

${ }^{1}$ Li-Yuan CAO, a researcher of Beijing Energy Development Research Base. 
would decide the development speed and scale of social organizations. Therefore, it has much significance for developing social organizations and transforming government functions to study the development process of relationship between government and social organizations since the foundation of the China. According to the background of social change and the different roles and functions of government and social organizations, we can divide the development process into 4 stages as following.

\section{Period of Control and Management (1949-1977)}

After the foundation of China, social organizations regained the space for survival and development. At that time the Ministry of the Interior and local governments improved and rectified illegal groups like Kuomintang reactionary organization, imperialistic and feudal groups, etc. At the same time, in accordance with Interim Measures on Registration of Social Groups (1950) and Enforcement Rules of Interim Measures on Registration of Social Groups (1951), people groups that meet the basic needs of political and social life were legally registered and given legitimacy. These social groups composed the essential part of social organizations in this stage. However, because our country was in totality society that time, and government was overall dominant of social affairs, so the introduction of a number of management practices didn't activate social groups actually but achieved "control" and "management". Therefore, the relationship between government and social organizations was in the period of control and management. During the Cultural Revolution, domestic areas have been hit badly, legislation of civil organizations has been suspended at one time, and social organizations fell into total paralysis.

\section{Period of Attachment and Dependence (1978-1990)}

After the Third Plenary Session in 1978, China has successively carried out economic system reform, political system reform and social system reform, when differentiation of social benefits increased and government functions began to transfer. Various social organizations get the space for development again, and started to actively participate in socialist modernization. Industry associations, academic groups, scientific groups, community organizations and others have made considerable progress in quantity and variety, and even independence have greatly enhanced than before. By 1989, the number of national social groups soared to 1600 , and the number of local social groups reached to more than 20 million.[2] However, since the reform mainly focused on the economic field, and political turmoil in 1989 made political and social reform stagnate, therefore, despite that it was different from previous "control and management", the relationship between government and social organizations at this stage was still a relationship of "attachment and dependency", and social organizations depended on government. Due to dual management system, social organizations had to rely on government from creation to run, especially in terms of capital structure, personnel rights, decision-making and volunteer resources.

\section{Period of Half-attachment and Half-independence (1993-2007)}

In 1993, the socialist market economy was established formally in China. With the development of market economy and deepening of government reform, market failure and transformation of government functions create great space for social organizations development, which freed social organizations from the relationship of "attachment and dependence" gradually, to the relationship of half-attachment and half-independence, presenting the feature of "dependent independence" ${ }^{\text {"[3] }}$. On one hand, grassroots social organizations displayed a good momentum and considerable independence; On the other hand, we can't ignore the fact that the majority of social organizations particularly government-organized social organizations were still attached to government. After the Notice about Party and Government Leading Cadres Can't Concurrently Hold the Leadership Positions of Social Groups in 1998, social organizations began to get rid of dependence on government to autonomy.

It should be stressed that the "half-attachment" in this phase is different from the "attachment" in last phase. Due to dual management system, grassroots social organizations must gain legal status through obtaining government's admission, so the attachment to government was a passive choice, 
which was different from former active attachment to competent business units.

\section{Period of Preliminary Exploration of Cooperative Partnership (2008-)}

2008 Wenchuan earthquake pushed social organizations in front of the public, and the government fully realized the vitality and value of social organizations, and took a series of measures to support and promote the development of social organizations. Since then, the relationship between government and social organizations has come to a new stage, and both of them have began to actively explore establishing partnerships. The 18th Party Congress and Third Plenary Session of the 18th CPC Central Committee provided regime security for reforming social organizations system and forming cooperative partnerships. Market model mainly the implementation of government purchase of services provided technical support for building partnership relations. The great-leap-forward development of social organizations in quantity and quality lay the foundation for forming a partnership. According to Ministry of Civil Affairs, as of the end of 2014, there were 606,000 social organizations, including 310,000 social groups, 4117 foundations, and 292,000 private non-enterprise units.[4] In short, the development of various undertakings can't separate from social organizations increasingly, and social organizations have become an indispensable force for socialist modernization.

\section{Main Experience of Historical Evolution of Relationship between Government and Social Organizations}

Among decades when relationship between government and social organizations changed, lots of experience of coordination and promoting cooperation has been accumulated, including the following aspects:

\section{Unified Leadership of CPC and Government Is the Premise of Development of Social Organizations}

As a socialist country, the development of Chinese social organizations must adhere to the united leadership of CPC and government, which is the fundamental difference between Chinese and Western countries on the relationship between government and social organizations.

Only by insisting on the unified leadership of CPC and government, can we give full play to the advantages of social organizations, and avoid the emergence of voluntary failure as far as possible. For example, effective government regulation can ensure legal use of charitable funds. Only by insisting on the unified leadership of CPC and government, can we strengthen the legitimacy of existence of social organizations, inhibiting the formation of illegal organizations effectively. For example, CPC and government attacked and banned cult like Falun Gong. Only by insisting on the unified leadership of CPC and government, can we ensure political correctness of social organizations and prevent alienation of social organizations.

\section{Promoting Social Organizations Is an Important Way to Improve Governmental Governance Capability}

Firstly, promoting social organizations will help improve economic governance capacity of government. Due to the inherent flaws of market economy and system defects in economic transition, non-legitimate competition and violation of law and other phenomena in operation of market appear, promoting social organizations especially like trade associations, consumer associations and other economic organizations will be in favor of maintaining the normal operation of market economy. In addition, many economic organizations protect legitimate rights and interests of domestic enterprises in international market actively, which enhance the international competitiveness of national economy.

Secondly, promoting social organizations will help improve social governance capacity of government. One function of social organizations is to undertake some government functions, making up for the government deficiency in provision of public goods and services. Promoting social organizations could help government maintain social order, deal with public crises, meet the 
diverse needs of community better, and innovate provision model of public services.

Thirdly, promoting social organizations could help innovate governance philosophy of government. In the process of management of social organizations, government has gradually transferred from control thinking to service thinking, from single body strategy to multiple subjects strategy, from hierarchy power idea to idea of democracy and rule of law, reflecting the promotion of governance philosophy.

\section{Reformation and Opening Is Powerful Driving Force to Developing Social Organizations}

Firstly, economy reform improved people's living standards dramatically, so the leisure time and social participation of the public increased. The operation mode of market economy also worked for cooperation between government and social organizations, such as government purchase social services. Secondly, market economy would fail sometimes, leading to new social problems and contradictions, which created space for emergence and development of social organizations. Thirdly, market economy requires the transformation of government functions. The economic micro-management functions need to be transferred out, and social management and service functions need the aid of social forces to fulfill, which provide conditions for the development of social organizations. Finally, reformation and opening made China integrate itself into international society from all aspects actively, and social organizations aren't exclusive of course. Especially after joining WTO, in accordance with international practice, Chinese economic cooperation and trade exchanges need to be in the charge of some special economic organization. Therefore, we must develop industry associations to take over some functions of government.

In addition, reformation and opening has created conditions for the integration between domestic and foreign social organizations. Foreign social organizations provide experience for us in organizational structure, decision-making mechanism and other aspects of social organizations. They were active in fields of environmental protection, poverty alleviation and especially AIDS, which greatly promoted the development of domestic social organizations and filled the void.

\section{Innovation is Main Way to Develop Social Organizations}

First of all, government innovated the management of social organizations. It's mainly shown in the following three aspects: Firstly, government innovated management regime of social organizations. Government perfected and amended relative policies and regulations constantly, including Regulation on Registration and Administration of Social Organizations, Regulation on the Administration of foundations, Provisional Regulations for the Registration Administration of People-Run non-Enterprise Units and so on. Government also issued decree about government and party cadres working in social organizations, party organization construction of social organizations, tax preference of social organizations and other issues. Secondly, government innovated management system of social organizations. Reforms of dual management system and modern social organizations system have broken the situations of decentralized management and centralized management in turn. Thirdly, government innovated management mechanism of social organizations. In access, participation, motivation, training, assessment and even withdraw of social organizations, government innovated management mechanism with new methods and tools.

Next, social organizations continue to innovate themselves. Firstly, social organizations innovated structure. Many project-operating foundations actively explored transformation into grant-making foundations, in order to provide fund, capacity, information and intellectual support to other social organizations, which made the structure of foundations more reasonable. Besides, the emerging social enterprise is a representative that achieved cross-border integration and innovated social governance successfully, whose advantage on solving social problems with commercial mode has become increasingly apparent. Secondly, social organizations innovated internal governance. Social organizations strengthened institutional construction, refined articles, established and improved electoral system and member's representative's conference system and so on, and the capacity have been continuously improved. Thirdly, social organizations innovated the means of mobilizing resources and implementing activities. They set up platforms through internet to recruit volunteers and release information, which has enhanced influence and transparency. 


\section{Enlightenments}

Combined with the historical evolution and main experience of relationship between government and social organizations since the foundation of china, this paper believes that there are following enlightenments for handling the relationship between government and society and promoting reform and construction:

\section{Develop and Perfect Social Organizations, Promoting Social System Reform}

Building cooperative partnership between government and social organizations needs to accelerate to promote social system reform. We should start from national strategic perspective, and accelerate to change dual management system to modern social organizations system, in order to form this kind of social management pattern-"unified registration, perform their duties, coordination and cooperation, graded responsibility, supervision according to law"; We should accelerate to promote the classified reform of public institutions, ensuring that social organizations achieve "incremental" development; We should accelerate to transform people's organizations functions, restore its representation of people, and make them actually work on resolving internal contradictions among people, flourishing social undertakings, and providing public service. In short, "follow the original idea of market development, on one hand, pay attention to breeding new social organizations, on the other hand, we must also pay attention to changing the functions and mechanisms of existing social organizations." ${ }^{[5]}$

\section{Promote the Transformation of Government Functions, Deepening Administrative System Reform}

Building cooperative partnership between government and social organizations needs to continue to deepen administrative system reform, whose core is transforming government functions. Government should put more focus on "service", strengthen social management and public service functions, authorize society further, reform administrative approval system, and reduce microscopic intervention. At the same time, play a predominant role, create a good environment from top to bottom, improve government functions system, broaden the entrance and supervise the process, and bring social organizations’ main part into full play in social governance.

\section{Innovate Government-society Relationship, Push Forward Political System Reform Actively and Steadily}

Building cooperative partnership between government and social organizations needs to push political system reform forward actively and steadily. The cooperation between government and society denied narrow state-society conflict theory, and promoted positive interaction of state and society, which has played an effective buffer action when the omnipotent government changed to limited government. At the same time, it created a favorable political environment for the development of social organizations, reflecting the transition from prevention to acceptance, from class struggle to negotiation, from rule of man to rule of law, consolidating the governing basis of CPC, promoting political democratization and legalization process.

\section{Summary}

In the long run, the flourish of social organizations is a bound demand of the development of times and society. With the advent of true civil society, social organizations will undertake government administrative functions, becoming the most active part of civil society, and play an irreplaceable beneficial role in field of public service provision.[6]

\section{Acknowledgment}

This paper is supported by Beijing Energy Development Research Base. 


\section{References}

[1] Ming WANG. Social Organizations in Transition-A New Perspective of NGO. Chinese Brand and Anti-counterfeiting, 2010,(1):12-14.

[2] Dong-Min WU, Xi-Ming CAO. Nonprofit Organization Management.Beijing: Renmin University of China Press, 2003:98.

[3] Shi-Zong WANG, Cheng-Cheng SONG. Independence or Autonomy: Rethinking Problem of Social Organizations in China. Social Sciences of China,2013,(5):50-66.

[4] Information on http://www.mca.gov.cn/article/zwgk/mzyw/201506/20150600832371.shtml

[5] Pei-Lin LI. Social Governance and Social System Reform. National Administration School Journal, 2014,(4):8-10.

[6] Wen-Li ZHANG. Cooperate and be strong altogether: Chinese Experience of Relationship of Government and Social Organizations in Field of Public Services. Chinese Administration, 2013,(6):7-11. 